\title{
Experiences with vaccines against cutaneous leishmaniasis : of men and mice
}

\author{
FARROKH MODABBER \\ UNDP/World Bank WHO Special Programme for Research and Training in Tropical Diseases, \\ World Health Organization, CH 1211, Geneva 27, Switzerland
}

\section{SUMMARY}

The need for a vaccine(s) against cutaneous leishmaniasis and the populations at risk for whom such vaccines should be developed are briefly discussed. The current human vaccine studies are reviewed, as are some experimental mouse studies with emphasis on Leishmania major infection relevant to vaccine development. Based on the information available from the mouse model and those data which are being sought in human studies, the benign nature of the cutaneous disease, the ease with which $L$. major can be manipulated to yield the required material, and the ongoing practice of leishmanization which allows rapid evaluation of candidate vaccine(s), it is suggested that a vaccine, at least against $L$. major, is imminent in the not too distant future.

Key words: cutaneous leishmaniasis, vaccines, Leishmania major, humans, mice.

\section{INTRODUCTION}

It was the observation that milkmaids who recover from cowpox are immune to infection with smallpox that prompted Jenner to perform his bold human experiment. Subsequently, cowpox virus ('vaccinia') became a vaccine against smallpox and the term 'vaccination' was applied to the general practice of immunization against an infective agent. Similarly, the term 'leishmanization' has recently been applied to an ancient practice of deliberate infection with Leishmania for the purpose of inducing a longlasting immunity against Old World Cutaneous Leishmaniasis (OWCL) which often involves multiple lesions in exposed areas of the body.

Clearly, this method of prophylactic immunization is not without risk and difficulties, as will be discussed later. However, in the absence of any other feasible or practical control measures, leishmanization was used in the past in the USSR (Kellina, personal communication) and Israel (Greenblatt, $1980,1988)$ and is being used on a large scale in Iran today (Nadim \& Javadian, 1988).

There are several excellent review articles on immunological studies of experimental leishmaniasis (Behin \& Louis, 1984; Liew, 1986; Blackwell, McMahon-Pratt \& Shaw, 1986; Mauel \& Behin, 1987; also see a collection of articles edited by Louis \& Milon, 1987; Muller, Pedrazzini, Farrell \& Louis, 1989). This report will therefore focus primarily on ongoing human studies and those of the L. major mouse model as they pertain to vaccine development.

WHO NEEDS A VACCINE?

An important issue to be considered for vaccine development is the population for whom vaccines are required. At present chemotherapy with antimonial drugs is expensive, treatment is required for a long time, produces side-effects, and is associated with numerous relapses and refractory cases. Indeed, it is not recommended to treat the zoonotic OWCL cases caused by L. major, unless multiple disfiguring or non-healing lesions are seen. The patients have no choice but to accept the suffering from a 6-9 month open ulcer(s) and the consequences of the nonaesthetic scar(s) which are left for the remainder of their lives. On the other side of the spectrum, visceral leishmaniasis (VL) of the Old World caused by $L$. donovani is presumably lethal if untreated once the signs and symptoms of the disease are well developed. In the visceral leishmaniasis (VL) caused by $L$. chagasi (and possibly $L$. infantum) the infection may be subclinical and self-healing in a relatively large number of cases. In certain individuals, perhaps due to factors like malnutrition, the infection will develop into a progressive disease which will require treatment (Badaro, Jones, Carvalho, Sampaio, Reed, Barral, Teixeira \& Johnson, $1986 b$; Badaro, Jones, Lorenço, Cerf, Sampaio, Carvalho, Rocha, Teixeira \& Johnson, 1986c). Subclinical infection with $L$. donovani has also been recognized by Sacks, Lal, Shrivastava, Blackwell \& Neva (1987).

Amongst the most difficult cases to cure, are the mucocutaneous (MCL) patients who cannot be definitively cured even with high doses of antimonials given for prolonged periods (Marsden, 1986).

Not knowing all the risk factors involved in the development of VL and MCL following the infection, it is difficult to know whether a vaccine

Parasitology (1989), 98, S49-S60 Printed in Great Britain 
should be used for a general population living in an endemic zone. The risks involved in injection of foreign material as a vaccine to healthy individuals, particularly children, must be carefully evaluated against the risks of getting the disease and the possible effects thereof. In addition, one must weigh the feasibility and cost of other control measures (to decrease the risk of disease) against those of vaccination. So far, with the limited information available, it seems that vaccination would be the most practical control tool for certain populations, if safe, effective and inexpensive vaccines were available. Certain groups have predictably a very high risk factor, for example, workers on new development projects, individuals from non-endemic regions who move to a highly endemic area, and children in hyperendemic regions where almost all are eventually infected. This is particularly true for zoonotic OWCL. These are obvious targets for vaccination but others must be carefully evaluated.

HOW MANY VACCINES ARE NEEDED AGAINST LEISHMANIASES?

Leishmaniasis is often referred to as a 'spectral' disease, because of the different clinical or pathological forms in which it can be presented. Indeed, some of the major forms (visceral and cutaneous) may be considered as different diseases, for they are normally caused by different species with completely different pathology, vector and reservoir specificity and ecology. Common features to all forms of leishmaniases are (a) large number of common antigens shared by different species, (b) all are transmitted by female sandflies, $(c)$ the sole target cell in the mammalian host is believed to be the macrophage and (d) generally, resistance to reinfection by the same organism follows a successful recovery from the original infection.

Despite the considerable antigenic cross-reactivity amongst Leishmania species, recovery from an infection does not confer immunity against others. However, some cross-protection has been noted, e.g. human infection with $L$. major is believed to produce a protective response against $L$. tropica infection (but not vice versa) and some experimental cross-reactivity has been demonstrated (reviewed by Mauel, 1982; Alexander \& Kaye, 1985; Mitchell \& Handman, 1987; Alexander, 1988).

Conceivably, a vaccine using some common antigens of the parasites might be effective against all forms of leishmaniases provided that they are presented by the appropriate antigen-presenting cells (APC) and can induce the protective $\mathrm{T}$ cell response. Unfortunately the characteristics of the antigens of different species of Leishmania presented on the surface of APC are not known.

Alternatively, an immune response against the common sandfly vectors which can enhance the virulence of the inoculum, as described recently (Titus \& Ribeiro, 1988) may induce a transmission blocking immunity which could be effective against several forms. A factor has been identified which closely resembles one of the peptides of the calcitonin-related gene products (CRGP). This peptide produces a strong vasodilation and local inflammatory reaction, thereby providing monocytes, target cells for Leishmania (Titus and Ribeiro, manuscript submitted). These points are highly theoretical and require further investigation.

\section{VACCINE DESIGN}

One might consider that most, if not all, effective vaccines used in humans so far, have been developed without knowing details of the mechanisms of protection, or the nature of the protective antigen (epitope). The empirical approach of vaccine development, therefore, should not be totally abandoned until vaccine design can be accomplished with the new technology.

The Scientific Working Group on Leishmaniases of the UNDP/World Bank/WHO Special Programme on Research and Training in Tropical Diseases (TDR) recommended that the Programme should simultaneously pursue several approaches, e.g. empirical approach using killed organisms for prophylactic immunization (Mayrink, Williams, Da Costa, Magalhaes, Melo, Dias, Lima, Michalick, Carvalho, Barros, Sessa \& de Alencar, 1985; Antunes, Mayrink, Magalhaes, Costa, Melo, Dias, Michalick, Williams, Lima, Vieira \& Schettini, 1986), and with BCG, for immunotherapy (Convit, Castellanos, Rondon, Pinardi, Ulrich, Castes, Bloom \& Garcia, 1987), semi-purified, or well-defined preparations showing promise in animal studies (Monjour, Ogunkolade, Pointet \& Vouldoukis, 1985; Handman \& Mitchell, 1985, 1987; Monjour, Ogunkolade, Vouldoukis, Roseto, Berneman \& Frommel, 1986; Frommel, Ogunkolade, Vouldoukis \& Monjour, 1988; Russell \& Alexander, 1988; Scott, Pearce, Nativitz \& Sher, 1987) and genetically engineered vaccine constructs which still require some fundamental development.

\section{WHAT KIND OF VACCINE IS NEEDED?}

An important requirement for many vaccines is that they must prevent infection. This may not be necessary for a vaccine against leishmaniasis, as discussed below, infection may exist without an observable pathological manifestation and disease prevention without interfering with infection may be an advantage.

Experiments in mice of different genetic background infected with L. major (Leclerc, Modabber, Deriaud \& Chedid, 1981) indicated that the organism remains viable in various organs long after the lesion 
is healed. One possible mechanism by which the parasites can evade the immune responses of the host is that they are able to hide within the 'safe targets' (pre-granulocyte-macrophage cells), which increase considerably during infection (Mirkovich, Galelli, Allison \& Modabber, 1986; Modabber, 1987). These cells presumably cannot be activated to kill the parasite (Hoover \& Nacy, 1984).

In humans, cell-mediated immune responses persist for many years following recovery from an infection (Wyler, Weinbaum \& Herrod, 1979). In my personal case a very strong delayed-type hypersensitivity (DTH) reaction to leishmanin as measured by skin test, was observed 14 years after living in a non-endemic area (almost 24 years after 3 lesions had healed). This strongly suggests that antigens or parasites persisted for a very long time after recovery from the infection. Furthermore an increasing number of patients with acquired immune deficiency syndrome (AIDS) or other form of immune deficiency are being reported also to suffer from recrudescent leishmaniasis (Badaro, Carvalho, Rocha, Queiroz \& Jones, 1986a; MartinezFernandez, Diaz, Sanchez, Carmena, Varela \& Navas, 1987; Verdejo, Alvar, Polo \& Lahoz, 1987; Clauvel, Couderc, Belmin, Daniel, Rabian \& Seligman, 1986; Medrano-Gonzalez, Lorenzo \& Perez, 1986; Senaldi, Cadeo, Carnevale, Di Perri \& Carosi, 1986; Franco-Vicario, Heredia, Rojo \& Hermosa, 1987; Mulliez, Dabouz, Demory, Darras \& Crinquette, 1987; Antunes, Carvalho, Tavares, Botas, Forte, Del Rio, Dutschmann, Costa, Abranches, Pereira, Paiva, Araujo \& Baptista, 1987). It has been suggested that leishmaniasis should be considered as an opportunistic disease (Badaro et al. $1986 a$ ).

All these observations indicate that at least in some cases, leishmaniasis produces a state of premunition (concurrent infection and immunity) which may be the underlying mechanism for prolonged immunity to reinfection generally seen in recovered individuals. Only when the immune response becomes deficient can the disease relapse.

If this is true, then the vaccine does not have to prevent infection to be disease-protective for the general population. This reduces the stringent requirements for a protective vaccine. In any case, for those living in an endemic region where they are continuously exposed to leishmanial antigens even a vaccine which can produce a short-term immunity may be sufficient when given at an appropriate time.

The degree of immunity is generally related to the dose of the virulent parasite given; while a low dose may be tolerated without producing a lesion, a high dose will overwhelm the immune response. Hence a vaccine which can only reduce the effective dose of the inoculum may be adequate for some populations who develop some degree of natural immunity as a result of repeated exposure to subinfective doses of the parasite.

On the other hand, repeated infection with the same organism has been reported in a few cases (e.g. Killick-Kendrick, Bryceson, Peters, Evans, Leaney \& Rioux, 1985). This may represent an aberrant immunological response induced by previous infections, genetic or other factors. Indeed, repeated infection may occur but it is usually milder and recovery is quicker. It must be noted that in highly endemic regions, following recovery from a natural infection, repeated infections are rare, at least in the ZCL area.

Cutaneous leishmaniasis is the most frequently occurring form of the disease and this is the form which probably imposes the highest economic loss, particularly in new development projects in the Latin American countries and the Middle East. As the disease is relatively benign and the immunity produced following recovery from the original infection is generally life-long for indigenous populations, the development of a vaccine seems the least difficult compared to vaccines against other forms. In certain populations of the ZCL-endemic areas, almost $100 \%$ will eventually become infected and age-related incidence remains predictably constant for children. This, in addition to the programmes of leishmanization, provides a special opportunity for evaluation of candidate vaccines. All these points indicate that a prophylactic vaccine against $\mathrm{ZCL}$ is feasible, beneficial, cost-effective and needed for those who live in or enter hyperendemic zones of OWZCL.

Development of a vaccine(s) against other forms of the disease, however, is not as simple and requires much more detailed information on the pathology of the disease, risk factors, etc.

An inexpensive vaccine which produces a life-long protection after a single administration without any side-effects would be ideal. Live vaccines which establish a state of premunition require one administration and produce a long-lasting protection. As Leishmania produce a state of premunition (shown in animal models and implied by the recrudescent VL in AIDS, patients without previous history of clinical leishmaniasis as mentioned above), a live vaccine should not be ruled out despite disappointing trials in the past (Heyneman, 1971).

The failure of previous vaccine trials has been attributed to changes of the parasite in culture, as indicated by Mauel (1982). The stability of the parasite must be assured in any vaccine development strategy. Changes of the characteristics of the parasites in culture have been re-examined elegantly for many Leishmania species in recent years (Giannini, 1974; Keithly \& Bienen, 1981; Sacks \& Perkins, 1984; Franke, McGreevy, Katz \& Sacks, 1985; Wozencraft \& Blackwell, 1987; Melo, Williams, Magalhaes-Rocha, Baba, Mayrink, Michalick, 
Da Costa, Diaz \& Magalhaes, 1987; Turco, Hull, Orlandi, Sheperd, Homans, Dweck \& Rademacher, 1987; Howard, Sayers \& Miles, 1987; Celeste \& Guimaraes, 1988), and inhibition of one species by another in a mixed culture has also been seen (Pacheco, Grimaldi \& Morel, 1987).

In addition, the isolate used for vaccination was not cloned as methods for cloning had not been developed and the possibility of a mixed Leishmania culture being used as the original vaccine preparation cannot be dismissed.

In recent years, biochemical and genetic analyses of Leishmania spp. have provided a large number of powerful tools and markers which can be used for characterization and identification of parasites, and to assure the stability of vaccines, whether a live or non-living vaccine is used (Arnot \& Barker, 1981; Wirth \& McMahon-Pratt, 1982; Jaffe \& McMahonPratt, 1983; Etges, Bouvier, Hoffman \& Bordier, 1985; Blackwell, 1985; Chang, Inserra, Kink, Fong \& Chang, 1986; Button \& McMaster, 1988; Puentes, Sacks, Da Silva \& Joiner, 1988).

The encouraging view of the prospects for a live vaccine is based on experimental vaccination of mice with non-pathogenic live clones of $L$. major (Mitchell, Handman \& Spithill, 1984). The genetically engineered organism carrying genes of protective antigens from different pathogens may not be as far-fetched as it seemed a few years ago (Jacobs, Tuckman \& Bloom, 1987).

\section{HUMAN VACCINATION}

At present there are 3 ongoing studies in human leishmaniasis. These employ living $L$. major (leishmanization, Nadim \& Javadian (1988)) ; a mixture of killed whole organisms (Mayrink et al. 1985 ; Antunes et al. 1986) and killed organisms plus BCG (Convit et al. 1987). The last is being used for immunotherapy although it may be considered in the future for prophylaxis.

These and the recent information gained from studies on experimental animals are the basis for renewed interest in pursuing vaccine development.

\section{LEISHMANIZATION}

The Iranian group has admitted to using leishmanization because all other attempts to control the disease in some communities had failed. As a result of the success obtained in these communities leishmanization was then used as a control method on a large scale because of the very high incidence of $\mathrm{ZCL}$ in and around the war zone border of I ran and Iraq. Recruits and volunteers were given the live inoculum about 3 months before being sent to endemic areas. The inoculum, approximately $2-3 \times 10^{5} \mathrm{~L}$. major in $0.1 \mathrm{ml}$ of supernatant fluid of 10-15 day NNN cultures was injected intradermally. The inoculum
Table 1. Leishmanization in Iran

(Data from Nadim \& Javadian (1988).

Recipient: 1200000 Soldiers

160000 Civilians around Isfahan

60000 Civilians, war refugees in Khuzestan

Vaccine: $\quad 2-3 \times 10^{5}$ live virulent Leishmania major (lesion of 5-10 mm for 4-6 months). 2-3\% large and non-healing lesions, requiring treatment.

Evaluation in some selected villages (1982). Vaccinated* (530), 14 infected $+(2 \cdot 6 \%)$; non-vaccinated (1724), 250 infected $(14 \cdot 15 \%)$.

* $77 \%$ takes.

$\dagger$ Lesions were smaller and healed quicker than infected individuals of non-vaccinated populations.

Skin test conversion $=93 \%$ in 'takes', $54 \%$ in 'nontakes' from another study.

therefore contained all the material present in the supernatant fluid of the medium, e.g. components of rabbit blood, agar, and any product of the parasite.

According to the report of Nadim \& Javadian (1988), over 200000 civilians and 1.25 million soldiers have received leishmanization within the past 6 years. The analysis of data is incomplete (see Table 1). However, it is reported that out of 8000 cases from the Isfahan area, 'less than 100' had received leishmanization. In general, those who had received inoculation had smaller lesions which healed sooner. In other independent studies, $77 \%$ of inoculated individuals developed a lesion due to inoculation (vaccine takes) and of these $93 \%$ were shown to produce a positive skin test. The skin test was positive in $54 \%$ of non-takes (those who were inoculated but did not develop a lesion).

The rate of skin test positivity in a normal population of age- and sex-matched children was not reported, but it must be much lower than this.

Needless to say this is not an acceptable control method except in extremely critical situations in which the incidence is very high and other methods are impracticable or ineffective. The 'vaccine' itself produces a lesion of $5-10 \mathrm{~mm}$ in diameter which lasts an average of 4-6 months, if no complication is produced. This is more than an acceptable sideeffect of many vaccines. Complications include large non-healing lesions which may last for years, requiring treatment, and immediate type hypersensitivity reactions which may last for a few hours with or without treatment. As the leishmanization programme introduced individuals with an active lesion to areas where CL was not present before (soldiers returning home) and some indigenous cases were subsequently reported, the question of initiating new foci of transmission has been raised by local authorities. If true (it seems unlikely), it would mean that for L. major, human-sandfly-human 
Hendricks, 1987; Peireira, Melo, Mayrink \& De Resende, 1988). Some of these studies are pertinent to vaccine development but will not be considered here. The bulk of information on immunology and pathology of leishmaniasis has been obtained from mouse models. This is because of the availability of cell markers, inbred, congenic and now even transgenic mice, in addition to all other attributes which have made the mouse the animal of choice for laboratory experimentation.

\section{The mouse}

Several laboratories discovered independently that the susceptibility of inbred mice to a given Leishmania species (infection caused by promastigotes) varies considerably and is controlled genetically (Kellina, 1973; Handman, Ceredig \& Mitchell, 1979; Behin, Mauel \& Sordat, 1979; Nasseri \& Modabber, 1979; Perez, Labrador \& Torrealba, 1979; Howard, Hale \& Liew, $1980 a$ ). Most inbred mice are resistant to $L$. major infection (recover spontaneously) and only a few, notably BALB/c and its $\mathrm{H}-2$ congenic strains are highly susceptible. These mice exhibit visceral disease and invariably die of a fulminating disseminated infection, even with injections of a very small inoculum (e.g. 100 organisms) compared to the $10^{6}$ organisms required to give a small self-healing lesion in resistant mouse strains. This exquisite susceptibility has fascinated many investigators who have used the $\mathrm{BALB} / \mathrm{c}-$ $L$. major model to study the immunology and also the chemotherapy of leishmaniasis. Unfortunately, L. major infection in BALB/c mice cannot be considered a model for any of the human leishmaniases.

The visceralization and the associated signs (changes in serum proteins, peripheral blood cells, anergy to skin test antigens, splenohepatomegaly, etc.) resemble human kala azar (Djoko-Tamnou, Leclerc, Modabber \& Chedid, 1981). However, a large lesion is initially produced at the site of inoculation and metastatic lesions develop subsequently quite unlike the human disease. The philosophy of using BALB/c mice for vaccine or drug studies is that if $\mathrm{BALB} / \mathrm{c}$ can be protected or cured then so can the resistant mouse strains which produce a benign self-healing disease similar to human zoonotic cutaneous leishmaniasis (ZCL). The danger is that some otherwise potentially useful reagents (drugs or vaccines) may be undetected because of the stringencies and peculiarities associated with the BALB/c-L. major model.

Influenced by epidemiological impressions, resistance to leishmaniasis has been attributed to cellmediated immunity as measured by the classical DTH reaction in humans, using leishmanin (phenolkilled Leishmania) in a skin test (Montenegro reaction). Early experiments with $T$ cell deprived (irradiated, thymectomized and bone-marrow recon- stituted) mice showed the involvement of $T$ cells in the pattern of the disease (Preston, Carter, Leuchars, Davies \& Dumonde, 1972). Mitchell et al. (1980) clearly demonstrated the role that $T$ cells play in immunity. The lack of DTH in infected BALB/c mice (Nasseri \& Modabber, 1979; Howard, Hale \& Liew, 1980b) and transfer of resistance together with DTH, by use of $\mathrm{T}$ cells from protected mice (reviewed by Mitchell, 1984), further pointed to a correlative, if not a causal relationship between DTH and resistance. In fact, in the era of dominance of suppressor $T$ cells in immunological phenomena, the susceptibility of $\mathrm{BALB} / \mathrm{c}$ mice was thought to be due to the induction of suppressor $T$ cells which specifically down-regulated DTH response (Liew, Hale \& Howard, 1982). The first indication that there was not a causal relation between DTH and resistance was obtained from studies on $F_{1} X$ backcross of $\mathrm{A} / \mathrm{J} \times \mathrm{BALB} / \mathrm{c}$ mice infected with $L$. major (Modabber, Alimohammadian, Khamesipour, Pourmand, Kamali \& Nasseri, 1980). The time of death after infection did not correlate with the presence or magnitude of the DTH response. The elegant works of Louis and his collaborators (Lima, Engers \& Louis, 1984; Milon, Titus, Cerottini, Marchal \& Louis, 1986) and Liew, Howard \& Hale, (1984) clearly showed that DTH is not the protective mechanism per se.

In the first successful immunization using killed organisms, Howard, Nicklin, Hale \& Liew (1982) showed that intraperitoneal (i.p.) or intravenous (i.v.) immunization with killed Leishmania rendered $\mathrm{BALB} / \mathrm{c}$ mice immune to $L$. major infection, yet the mice at the time of challenge were DTH-negative. The classical observation by Titus, Lima, Engers \& Louis (1984) that Leishmania-specific $T$ cell lines which can activate infected macrophages to kill the parasite in vitro will exacerbate the disease when transferred in vivo, was surprising but crucial in the understanding of the mechanism of the host-parasite relationship. Not only did it become clear that in vitro observations could not simply be extrapolated to in vivo situations, but these findings showed that activation of macrophages to kill intracellular parasites per se was not sufficient to control the disease. Other factors, such as $(a)$ different cytokines or $(b)$ parasite products, might override the crucial effector mechanism, macrophage activation. Evidence for both mechanisms exists: (a), firstly infected BALB/c mice produce an inexplicably high concentration of colony stimulating factors (CSF) and a high number of granulocyte-macrophage colony forming cells in culture (GM CFU-c, immature monocytes) (Mirkovich et al. 1986). These premature cells act as 'safe targets' for the parasite, presumably because they cannot be activated to kill the parasites (Hoover $\&$ Nacy, 1984). Titus et al. (1984) noted that exacerbating $\mathrm{T}$ cells induced accumulation of macrophages at the site of the lesion, and also suggested that this 
may be a mechanism by which the disease is exacerbated. In support of the 'safe target' hypothesis are the observations that administration of recombinant CSF (Solbach, Greil \& Rollinghoff, 1987) or IL-3, multi-colony stimulating factor acting on bone-marrow precursor cells (Feng, Louis, Kindler, Pedrazzini, Eliason, Behin \& Vassalli, 1988), will aggravate the disease in mice.

Alternatively, these lymphokines may directly affect the mediators of macrophage activation, such as gamma-interferon (IFN), as suggested by the more recent results of Liew et al. (submitted for publication). These investigators have presented evidence indicating that the 'exacerbating' $T$ cells produce factors which can inhibit the IFN-mediated activation of macrophages and thereby prevent intracellular killing of Leishmania. The factors involved are identified as interleukin 3 (IL-3) and IL-4 (B cell stimulating factor also affects mast cell differentiation). This observation is crucial for explaining exacerbation of the disease in the presence of large numbers of effector $\mathrm{T}$ cells in BALB/c mice and the possible mechanism by which the unbalanced $\mathrm{T}$ cell populations would lead to modification of the immune responses (reviewed by Muller et al. 1989).

Recently, Kaufmann \& Flesch (1988) have shown that IL-4 and IL-5 (eosinophil differentiation factor) potentiate the IFN-mediated activation of macrophages to kill Mycobacteria and other intracellular organisms. This is an apparent contradiction with the observations of Liew et al. (submitted). The difference in the experimental design and the state of 'activation' required for killing bacteria versus Leishmania may account for this apparent contradiction. The subdivision of T-helper (L3T4+) cells into the two groups $\mathrm{TH} 1$ and $\mathrm{TH} 2$ on the basis of lymphokine production (Mosmann \& Coffman, 1987), provides an explanation for the dual and contradictory roles described for $\mathrm{L} 3 \mathrm{~T} 4+$ Leishmania-specific $\mathrm{T}$ cells, mediating resistance as well as abrogation of resistance (Liew et al. 1982; Titus, Milon, Marshal, Vassali, Cerottini \& Louis, 1987). Disregarding some overlap between the two cell types, $\mathrm{TH} 1$ and $\mathrm{TH} 2$ cells are distinguished by production of IFN and IL-4, respectively. It follows then that TH1 cells would be expected to protect and TH2 cells to exacerbate. Indeed, Locksley, Heinzel, Sadick, Holaday \& Gardner (1987) have shown that resistance in mice correlates with the ability to produce TH1-type cells.

Secondly, (b), parasite products may directly interfere with the mechanism of activation of macrophages (Handman, Schnur, Spithill \& Mitchell, 1986). It has been shown by Flesch \& Kaufmann (personal communication) that products of $M$. leprae can suppress the IFN-mediated activation of bonemarrow derived mononuclear phagocytes in vitro.

It is not known what factors influence the induction of different subpopulations of cells. Operationally, the route of injection and the use of adjuvants determine the predominant cell type induced, for example, subcutaneous injection of leishmanial antigens with Freund's complete adjuvant will lead to preferential induction of exacerbating cells (TH2), while i.v. or i.p. injections of the parasite lead to predominant generation of protective $\mathrm{T}$ cells (TH1). This may appear to be a major problem in the development of human vaccines. However, as mentioned above, numerous studies in humans indicate that exposure to the leishmanial antigens via the cutaneous route does not sensitize the individual to produce an exacerbated disease when subsequently infected with Leishmania (Mayrink et al. 1985; Antunes et al. 1986; Nadim, personal communication). More recently, Russell \& Alexander (1988) have shown that leishmanial antigens, particularly the promastigote surface protease (gp63) and the major surface glycoconjugate of Handman, Greenblatt \& Goding (1984), a component of the excretory factor described by Schnur, Zuckerman \& Greenblatt (1972), could induce a protective immune response when incorporated in liposomes. This immunity was shown to be transferable by $\mathrm{T}$ cells. Hence presentation of antigen can profoundly affect the ensuing immune responses.

The specificity of the protective cells (presumably TH1) and the exacerbating L3T4+ cells (presumably $\mathrm{TH} 2$ ) are not known. Is there a repertoire restriction of epitope specificity? This question is obviously very important in developing molecularly defined vaccines. If the specificity of $\mathrm{TH} 1$ cells is limited to certain antigenic moieties, then the choice of molecules would be of crucial importance. On the other hand, if there is no restriction with respect to epitope specificity for $\mathrm{TH} 1$ and $\mathrm{TH} 2$, then a large number of immunogenic molecules could be used effectively, provided that they are presented in a form (right vehicle, adjuvant, carrier and route of injection) that can preferentially or exclusively induce a TH1 response. Data to support both arguments exist. According to Mitchell \& Handman (1986) the carbohydrate part of the LPG, is a 'suppressogenic' molecule - an unfortunate term to denote a 'parasite-protective' molecule (a better term used by the same authors)-e.g. a TH2stimulating immunogen, whereas the whole molecule (LPG) would be a TH1-inducing and hence a protective immunogen.

The mechanism of exacerbation produced by the carbohydrate alone is not known, nor is the specificity of $T$ cells produced after carbohydrate injection. Do $T$ cells recognize the carbohydrate, or is the exacerbation mediated by $B$ cells and their products? In other words, does the carbohydrate moiety induce a $\mathrm{TH} 2$ response directly or via $\mathrm{B}$ cells? It is known that carbohydrate immunogens only stimulate antibody formation and not DTH. 
The protective effect of anti- $\mu$ treatment of BALB/c (Sacks, Scott, Asofsky \& Sher, 1984) is compatible with a B cell-mediated susceptibility.

A more attractive hypothesis is that the nature of the response is regulated by the antigen-presenting cells (APC). In this model, the repertoire of $T$ cell specificity is not so limited as to exclude certain groups of epitopes (including carbohydrate epitopes). Hence, if the epitope is presented properly and all the required stimuli are available, the specific $T$ cell clone will be stimulated. The observation of Russell \& Alexander (1988) with gp63 in liposomes, supports this notion. If so, then selection of molecularly defined potential vaccines would be easier and would be based on their presence on those APC which best induce a TH1 equivalent response in humans. Several cell types are known to be APC, e.g. macrophages, dendritic cells and $B$ cells. Of these, it is expected that B cells would not be the APC of choice for a protective response against leishmaniasis, for the reasons mentioned above. The analysis of antigens presented by APC (other than B cells) would be crucial in the selection of molecularly defined vaccines.

One of the most important achievements of recent years in the study of murine leishmaniasis is the generation of $T$ cell lines and clones which can protect $\mathrm{BALB} / \mathrm{c}$ mice against an otherwise lethal challenge of $L$. major. This has been accomplished in two laboratories independently. Muller \& Louis (submitted for publication, reviewed by Muller $\mathrm{et} \mathrm{al}$. 1989) have established two protective cell lines which recognize only antigens associated with the live Leishmania. These cells were generated in the presence of live Leishmania, in contrast to the previously generated $\mathrm{T}$-cell lines and clones which were all exacerbating and for which parasite extracts were used. These authors believe that to be protective, $T$ cells must recognize an antigen associated with the live parasite, since the $T$ cells must be able to activate infected macrophages (containing live parasites) in order to be protective. Otherwise T cells which can only recognize antigens on the surface of the macrophages which have ingested dead parasites, could not be protective even if they are of the TH1 type. This model argues very strongly for the importance of epitope specificity and imposes a new requirement for $\mathrm{TH} 1$ cells in order to be protective. Use of the TH1 versus TH2 model to explain the diversity of functions by cells of the same phenotype would still remain valid if macrophages which have ingested dead parasites would also present some antigens presented by the infected macrophages and vice versa. It follows that only a proportion of TH1 cells would be involved in elimination of the infection. This proportion depends on the number of common antigens present on the surface of macrophages which have ingested dead organisms and the ones infected with the live parasites. The analysis of antigens present on these two types of macrophages is important.

Scott, Natovitz, Coffman, Pearce \& Sher (1988) have used a protective fraction of the parasite, which they had identified previously (Scott et al. 1987), to generate their protective line from which they have produced a protective clone. These cells, in contrast to those produced by Muller \& Louis (1989), mentioned above, will recognize the protective fraction without requiring live parasites. It is not known whether the antigen recognized is present on the surface of infected macrophages, a feature which would support Muller $\&$ Louis's model.

The protective fraction of Scott et al. (1988) may contain the antigen or be the one that is also presented on the surface of infected macrophages. On the other hand, the specificity of the protective clones of Muller and Louis may have been achieved totally by chance and it may be that if many more clones are produced, antigens common to infected macrophages and macrophages that have ingested dead parasites, or a fraction thereof, would be found. Nevertheless, the specificity and functional analysis of these and future protective cells will be needed to understand the mechanism of immunity.

The requirements for an immunogen to be protective, extrapolated from the mouse studies as they are known today, seem to be the following. First, the immunogen must be presented in such a way that it would not produce a local inflammatory reaction (see Titus \& Ribero, 1988). Second, the immunogen must be introduced so that it will be presented by the appropriate APC which can induce the desired immune responses (see Russell \& Alexander, 1987). Third, the immunogen must induce predominantly, if not exclusively, a TH1 type $\mathrm{T}$ cell response, i.e. IFN-producing in the mouse (see Locksley et al. 1987), or their equivalent in the human, if they exist. These cells must recognize an epitope on the surface of infected macrophages, since activation of the infected macrophage is the necessary mechanism required for killing of the intracellular parasites (see Muller et al. 1989). Fourth, the immunogen must not produce a strong $\mathrm{T}$ or $\mathrm{B}$ cell stimulation (see Mitchell, Handman, Moll, McConville, Spithall, Kidane, Samaras \& Elhay (1987) and Milon et al. (1986) on enhanced T cell response, and Colle et al. (1983) and Lohoff, Matzner \& Rollingholl (1988) on polyclonal $B$ cell response).

With the information available, the ease with which $L$. major can be cultured, the relatively benign nature of cutaneous leishmaniasis and the possibility of testing candidate immunogens in man, it is not surprising that some of us 'Leishmaniacs' are very optimistic and believe that if BALB/c mice can be protected now, humans will be protected in the not too distant future. 
The author is indebted to Drs P. Castellanos, I. Flesch, J. Louis, F. Y. Liew, I. Muller, P. Scott and R. Titus for providing unpublished data and/or manuscripts, and to Mrs E. Borbor, Mrs M. Haegglund and $\mathrm{Mr} \mathrm{W}$. Keenan for assisting with the manuscript and to Dr P. de Raadt and $\mathrm{Mr} \mathrm{R}$. Modabber for reading it critically.

\section{REFERENCES}

ALEXANDER, J. (1988). Sex differences and crossimmunity in DBA/2 mice with cutaneous leishmaniasis correlates with the capacity to generate interleukin 3 in response to Leishmania antigen in vitro. Cellular Immunology 111, 66-76.

ALEXANDER, J. \& KAYE, P, M. (1985). Immunoregulatory pathways in murine leishmaniasis: different regulatory control during Leishmania mexicana mexicana and Leishmania major infections. Clinical and Experimental Immunology 61, 674-82.

antunes, F., CaRvalho, C., TAVAREs, L. Botas, J., Forte, M., DEL RIO, A. M., DUTSCHMANN, L., COSTA, A., abranches, P., PEReira, C. S., PEIVA, J. E. D. araujo, F. C. \& BAPTISTA, A. (1987). Visceral leishmaniasis recrudescence in a patient with AIDS. Transactions of the Royal Society of Tropical Medicine and Hygiene 81, 595.

ANTUNeS, C. M. F., Mayrink, W., Magalhaes, P. A., COSTA, A., MELO, M. N., DIAS, M., MICHALICK, M. S. M., WILliams, P., LIMA, A. O., VIERRA, J. B. F. \& SCHETINI, A. P. M. (1986). Controlled field trials of a vaccine against New World cutaneous leishmaniasis. International fournal of Epidemiology 15, 572-80.

ARNOT, D. E. \& BARKER, D. C. (1981). Biochemical identification of cutaneous leishmaniasis by analysis of kinetoplast DNA. Il. Sequence homologies in Leishmania kDNA. Molecular Biochemistry and Parasitology 3, 47-56.

Badaro, R., CARVAl.ho, E. M., ROCHA, H., QUeIROZ, A. C. \& JONES, T. C. (1986a). Leishmania donovani : an opportunistic microbe associated with progressive disease in three immunocompromised patients. Lancet, i 647-8.

Badaro, R., Jones, T. C., CARVAlHo, E. M., SAMPaio, D., REED, S. G., BARRAL, A., TEIXEIRA, R. \& JOHNSON, W. D. JR. $(1986 b)$. New perspectives on a subclinical form of visceral leishmaniasis. Yournal of Infectious Diseases 154, 1003-11.

BADARO, R., JONES, T. C., LORENÇO, R., CERF, B. J., Sampaio, D., Carvalho, E. M., Rocha, H., Teixeiras, R. \& JOHNSON, W. D., JR $(1986 c)$. A prospective study of visceral leishmaniasis in an endemic area of Brazil. Fournal of Infectious Diseases 154, 639-49.

BEHIN, R. \& LOUIS, J. (1984). Immune response to Leishmania. Critical Reviews in Tropical Medicine 2, 141-88.

BEHIN, R., MAUEL, J. \& SORDAT, B. (1979). Leishmania tropica: pathogenicity and in vitro macrophage function in strains of inbred mice. Experimental Parasitology 48, 81-90.

BLACKWELL, J. M. (1985). Receptors and recognition mechanisms of Leishmania species. Transactions of the Royal Society of Tropical Medicine and Hygiene 79, 606-12.

BLACKWELL, J., MCMAHON-PRATT, D. \& SHAW, J. (1986).
Molecular biology of Leishmania. Parasitology Today 2, 45-54.

BUtTON, L. L. \& McMASTER, w. R. (1988). Molecular cloning of the major surface antigen of Leishmania. fournal of Experimental Medicine 167, 724-9.

CELESTE, B. J. \& GUIMARAES, M. c. (1988). Growth curves of Leishmania braziliensis braziliensis promastigotes and surface antigen expression before and after adaptation to Schneider's Drosophila medium as assessed by anti-Leishmania human sera. Revista do Instituto de Medicina Tropical de São Paulo 30, 63-7. CHANG, C. S., INSERRA, T. J., KINK, H. A., FONG, D. \& CHANG, K. P. (1986). Expression and size heterogeneity of a 63 kilodalton membrane glycoprotein during growth and transformation of Leishmania mexicana amazonensis. Molecular and Biochemical Parasitology 18, 197-210.

CHRISTENSEN, H. A. \& VASQUEZ, A. M. (1981). Susceptibility of Aotus trivirgatus to Leishmania braziliensis and L. mexicana. American Yournal of Tropical Medicine and Hygiene 30, 54-6.

Clauvel, J. P., COUderc, L. J., BElmiN, J., DaNiel, M. T., RABIAN, C. \& SELIGMAN, M. (1986). Visceral leishmaniasis complicating acquired immunodeficiency syndrome (AIDS). Transactions of the Royal Society of Tropical Medicine and Hygiene 80, 1010-11.

COLLE, J. H., TRUFFA-BACCHI, P., CHEDID, L. \& MODABBER, F. (1983). Lack of a general immunosuppression during $L$. tropica infection in BALB/c mice: augmented antibody response to thymo-independent antigens and polyclonal activation. Fournal of Immunology 131, 1492-5.

CONVIT, J., ARANZAZU, N., ULRICH, M., PINARDI, M. E., REYES, O. \& ALVARADO, J. (1982). Immunotherapy with a mixture of Mycobacterium leprae and BCG in different forms of leprosy and Mitsuda-negative contacts. International Yournal of Leprosy 50, 415-24.

Convit, J., Castellano, P. L., RONDON, A., PINARd, M. E., ULRICH, M., CASTES, M., BLOOM, B. \& GARCIA, L. (1987). Immunotherapy versus chemotherapy in localised cutaneous leishmaniasis. Lancet i 401-4. DENNIS, V. A., CHAPMAN, W. L. JR., HANSON, W. L. \& LUJAN, R. (1985). Leishmania donovani : clinical, hematologic and hepatic changes in squirrel monkeys (Saimiri sciureus). Yournal of Parasitology 71, 576-82. DENNIS, v. A., LUJAN, R., CHAPMAN, W. L. JR. \& HANSON, w. L. (1986). Leishmania donovani : cellular and humoral immune responses after primary and challenge infections in squirrel monkeys, Saimiri sciureus. Experimental Parasitology 61, 319-34.

DJOKO-TAMNOU, J., LECLERC, C., MODABBER, F. \& CHEDID, L. (1981). Studies on visceral Leishmania tropica infection in BALB/c mice. 1. Clinical features and cellular changes. Clinical Experimental Immunology 46, 493-8.

ETGES, R. J., BOUVIER, J., hOFFMAN, R. \& BORDIER, C. (1985). Evidence that the major surface proteins of three Leishmania species are structurally related. Molecular and Biochemical Parasitology 14, 395-400.

FENG, Z. Y., LOUIS, J. A., KINDLER, v., PEDRAZZINI, T., Eliason, J., BEHIN, R. \& VASSALli, P. (1988).

Aggravation of experimental cutaneous leishmaniasis in mice by administration of interleukin 3. European fournal of Immunology 18, 1245-51. 
FRANCO-VICARIO, R., DE HEREDIA, J. M. B., ROJo, P. \& HERMOSA, C. (1987). Leishmaniosis asociada al sindrome de la immunodeficiencia acquirida. Medicina Clinica 88, 565.

FRANKE, E. D., MCGREEVY, P. B., KATZ, P. \& SACKS, D. L. (1985). Growth cycle-dependent generation of complement-resistant Leishmania promastigotes. Fournal of Immunology 134, 2713-18.

FROMMEL, D., OGUNKOLADE, W., vOULDOUKIS, I. \& MONJOUR, L. (1988). Vaccine-induced immunity against leishmaniasis in BALB/c mice. Infection and Immunity 56, 843-8.

GIANNINI, M. S. (1974). Effects of promastigote growth phase, frequency of subculture, and host age on promastigote-initiated infections with Leishmania donovani in the golden hamster. Fournal of Protozoology 21, 521-7.

GITHURE, J. I., REID, G. D. F., BENHAZIM, A. A., ANJILI, C. O., SHATRY, A. M. \& HENDRICKS, L. D. (1987).

Leishmania major: the suitability of East African nonhuman primates as animal models for cutaneous leishmaniasis. Experimental Parasitology 64, 438-47.

GREENBLATT, C. L. (1980). The present and future of vaccination for cutaneous leishmaniasis. In $N e w$ Developments with Human and Veterinary Vaccines (ed. A. Mizrahi, I. Hertman, M. A. Klinberg and A. Kohn), pp. 259-85. New York: Alan R. Liss. GREENBLATT, C. L. (1988). Cutaneous leishmaniasis : the prospects for a killed vaccine. Parasitology Today 4, 53-4.

HANDMAN, E., CEREDIG, R. \& MITCHELl, G. F. (1979). Murine cutaneous Leishmaniasis: disease patterns in intact and nude mice of various genotypes and examination of some differences between normal and infected macrophages. Australian Journal of Experimental Biology and Medical Science 57, 9-29.

HANDMAN, E., GREENBLATT, C. L. \& GODING, J.W. (1984). An amphipathic sulphated glyucoconjugate of Leishmania : characterization with monoclonal antibodies. European Molecular Biology Organization fournal 3, 2301-6.

HANDMAN, E. \& MITCHELl, G. F. (1985). Immunization with Leishmania receptor for macrophages protects mice against cutaneous leishmaniasis. Proceedings of the National Academy of Sciences, USA 5910-14. HANDMAN, E. \& MITCHELl, G. F. (1987). Leishmaniamacrophage interaction: role of parasite molecules in infection and host protection. In Molecular Strategies of Parasitic Invasion (ed. N. Agabian, H. Goodman and M. Nogueira), pp. 493-500. New York: Alan K. Liss.

HANDMAN, E., SCHNUR, L. F., SPITHILL, T. W. \& MITCHELL, G. F. (1986). Passive transfer of Leishmania lipopolysaccharide confers parasite survival in macrophages. Yournal of Immunology 137, 3608-13. HEYNEMAN, D. (1971). Immunology of leishmaniasis. Bulletin of the World Health Organization 44, 499-514.

HoOveR, D. L. \& NACY, C. A. (1984). Macrophage activation to kill $L$. tropica : defective intracellular killing of amastigotes by macrophages elicited with sterile inflammatory agents. Yournal of Immunology 132, 1487.

HOWARD, J. G., HALE, C. \& LIEW, F. Y. (1980a).

Immunological regulation of experimental cutaneous leishmaniasis. I. Immunogenetic aspects of susceptibility to Leishmania tropica in mice. Parasite Immunology 2, 303-14.

HOWARD, J. G., HALE, C. \& LIEW, F. Y. (1980b). Immunological regulation of experimental cutaneous leishmaniasis. III. The nature and significance of specific suppression of cell-mediated immunity in mice highly susceptible to $L$. tropica, Fournal of Experimental Medicine 152, 594-607.

HOWARD, J. G., NICKLIN, S., HALE, C. \& LIEW, F. Y. (1982). Prophylactic immunization against experimental leishmaniasis. I. Protection induced in mice genetically vulnerable to fatal Leishmania tropica infection. Yournal of Immunology 129, 2002-12.

HOWARD, K. M., SAYERS, G. \& MILES, M. A. (1987). Leishmania donovani metacyclic promastigotes: transformation in vitro, lectin agglutination, complement resistance and infectivity. Experimental Parasitology 64, 147-56.

JACOBS, W. R. JR., TUCKMAN, M. \& BLOOM, B. R. (1987). Introduction of foreign DNA into mycobacteria using a shuttle plasmid. Nature, London 327, 532-5.

JAFFE, C. \& MCMAHON-PRATT, D. (1983). Monoclonal antibodies specific for Leishmania tropica. Fournal of Immunology 131, 1987-93.

KaUfManN, S. H. E. \& FLeSCH, I. E. A. Cell-mediated immunity, immunodeficiency and microbial infections. Current Topics in Infectious Diseases and Clinical Microbiology (in the Press).

KELLINA, O. I. (1973). Differences of susceptibility of inbred mice of different strains to L. tropica major Medical Parasitology 42, 279-80.

KEITHLY, J. A. \& BIENEN, E. J. (1981). Infectivity of Leishmania donovani primary culture promastigotes for golden hamsters. Acta Tropica 38, 85-9.

KILLICK-KENDRICK, R., BRYCESON, A. D. M., PETERS, W., EVANS, D. A., LEANEY, A. J. \& RIOUX, J.-A. (1985). Zoonotic cutaneous leishmaniasis in Saudi Arabia: lesions healing naturally in man followed by a second infection with the same zymodeme. Transactions of the Royal Society of Tropical Medicine and Hygiene 79, 363-5.

LAINSON, R. \& BRAY, R. S. (1966). Studies on the immunology and serology of leishmaniasis. II. Cross-immunity experiments among different forms of American cutaneous leishmaniasis in monkeys. Transactions of the Royal Society of Tropical Medicine and Hygiene 60, 526-32.

LAINSON, R. \& SHAW, J. J. (1977). Leishmaniasis in Brazil. XII. Observations on cross-immunity in monkeys and man infected with Leishmania mexicana mexicana, $L$ m. amazonensis, L. braziliensis braziliensis, L. $b$. guyanensis, and L. b. panamensis. Transactions of the Royal Society of Tropical Medicine and Hygiene 80 , 29-35.

LECleRC, C., MODABBER, F., DERIAUd, F. \& CHEDID, L. (1981). Systemic infection of Leishmania tropica (major) in various strains of mice. Transactions of the Royal Society of Tropical Medicine and Hygiene 75, $851-4$.

LIEW, F. Y. (1986). Cell-mediated immunity in experimental cutaneous leishmaniasis.

Parasitology Today 2, 264-70.

LIEW, F. Y., HaLE, C. \& HoWARD, J. G. (1982).

Immunologic regulation of experimental cutaneous 
leishmaniasis. V. Characterization of effector and specific suppressor T cells. Fournal of Immunology 128, 1917-22.

Liew, F. Y., hOWARD, J. G. \& HALE, C. (1984). Prophylactic immunization against experimental leishmaniasis. III. Protection against fatal Leishmania tropica infection induced by irradiated promastigotes involves Lyt $-1 \pm 2-T$ cells that do not mediate cutaneous DTH. Journal of Immunology 132, 456-61.

LIMA, G. C., ENGERS, H. D. \& LOUIS, J. A. (1984), Adoptive transfer of delayed type hypersensitivity reactions specific for Leishmania major antigens to normal mice using murine $\mathrm{T}$-cell populations and clones generated in vitro. Clinical and Experimental Immunology 576, 130-8.

LOCKSLEY, R. M., HEINZEL, F. P., SADICK, M. B., HOLADAY, B. J. \& GARDNER, K. D. JR., (1987). Murine cutaneous leishmaniasis: susceptibility correlates with differential expansion of helper T-cell subsets. Twentieth Forum in Immunology, Annales de l'Institut Pasteur/Immunologie 138, 744-9.

LOHOFF, M., MATZNER, C. \& ROLLINGHOLL, M. (1988). Polyclonal B-cell stimulation by L3T $4+\mathrm{T}$ cells in experimental leishmaniasis. Infection and Immunity 56, 2120-4.

LOUIS, J. \& MILON, G. (1987). Immunology of experimental leishmaniasis. Twentieth Forum in Immunology, Annales de l'Institut Pasteur/Immunologie 138, 219-27.

MARSDEN, P. D. (1986). Mucosal leishmaniasis ('espundia' Escomel, 1911). Transactions of the Royal Society of Tropical Medicine and Hygiene 80, 859-76.

MARTINEZ-FERNANDEZ, R., DIAZ, G. J. D., SANCHEZ, G. J., CARMENA, C. E., VARELA, L. N NAVAS, A. F. (1987). Leishmaniasis visceral en pacientes adictos a drogos por via parenteral, VIH positivos. Medicine Clinica (Barcelona) 88, 509-11.

MAUEL, J. (1982). Recent advances in the immunology of leishmanial infections (with particular reference to the problem of vaccination). Pontificiae Academia Scientiarum Scripta Varia 47, 91-112.

MAUEL, J. \& BEHIN, R. (1987). Immunity: clinical and experimental. In The Leishmaniases (ed. W. Peters and R. Killick-Kendrik), vol. 2, pp. 731-91. London: Academic Press.

MaYrink, W., Williams, P., Da Costa, C. A., MagalhaEs, P. A., MELO, M. N., DIAS, M., LIMA, A. O., MiChalick, M. S. M., CARVAlho, E. F., Barros, G. C., SESSA, P. A. \& DE ALENCAR, J. E. (1985). An experimental vaccine against American dermal leishmaniasis: experience in the State of Espirito Santo, Brazil. Annals of Tropical Medicine and Parasitology 79, 259-69.

MEDRANO gONZALEZ, F., LORENZO, A. A. \& PEREZ, B. J. L. (1986). Leishmaniosis visceral de curso fatal asociada infección por HTLV-III. Medicina Clinica (Barcelona) 87, 780-1.

MELo, M. N., Williams, P., Williams, P., MagalhaesROCHA, N. M., BABA, E. H., MAYRINK, W., MICHALICK, M. S. M., DA COSTA, C. A., DIAZ, M. \& MaGalhaES, P. A. (1987). The change of behaviour of two strains of Leishmania after cultivation in a defined medium. Memórias do Instituto Oswaldo Cruz, Rio de Ganeiro 82, 557-61.

MILON, G., TITUS, R. G., CEROTTINI, J. C., MARChal, G. \& Louis, J. A. (1986). Higher frequency of $L$. major- specific L3T $4+\mathrm{T}$ cells in susceptible mice as compared with resistant CBA mice. fournal of Immunology 136, 1467.

MIRKOVICH, G. F., GALELli, A., Allison, A. C. \& MODABBER, F. (1986). Increased myelopoiesis during L. major infection in mice: generation of 'safe target', a possible way to evade the effector immune mechanism. Clinical Experimental Immunology 64, 1-7. mitchell, G. F. (1984). Host-protective immunity and its suppression in a parasitic disease: murine cutaneous leishmaniasis. Immunology Today 5, 224-6. MITCHELL, G. F., CURTIS, J. M., HANDMAN, E. \& MCKENZIE, I. F. C. (1980). Cutaneous leishmaniasis in mice: disease patterns in reconstituted nude mice of several genotypes infected with Leishmania tropica. Australian Fournal of Experimental Biology and Medical Science 58, 521-32.

MitChell, G. F. \& HANDMAN, E. (1986). The glycoconjugate derived from a $L$. major receptor for macrophages is a suppressogenic, disease-promoting antigen in murine cutaneous leishmaniasis. Parasite Immunology 8, 255-63.

MITCHELL, G. F. \& HANDMAN, E. (1987). Heterologous protection in murine cutaneous leishmaniases. Immunology and Cell Biology 65, 387-92.

MITCHELI, G. F., HANDMAN, E. \& SPITHILL, T. W. (1984). Vaccination against cutaneous leishmaniasis in mice using nonpathogenic cloned promastigotes of Leishmania major and importance of route of injection. Australian fournal of Experimental Biology and Medical Science 62, 145-53.

MitChell, G. F., HANDMAN, E., MOLL, H., MCONVILle, M. J., SPITHILL, T. W., KIDANE, G. Z., SAMARAS, N. \& ELHAY, M. J. (1987). Resistance and susceptibility of mice to Leishmania major: a view from Melbourne. Annales de l'Institut Pasteur/Immunologie 138, 738-43. MODABBER, F. (1987). A model for the mechanism of sensitivity of BALB/c mice to L. major and premunition in leishmaniases. Annales de l'Institut Pasteur/Immunologie 38, 781-6.

MODABBER, F. Z., ALIMOHAMMADIAN, A., KHAMESIPOUR, A., POURMAND, M. H., KAMALI, M. H. \& NASSERI, M. (1980). Studies on the genetic control of visceral leishmaniasis in BALB/c mice by L. tropica. In Genetic Control of Natural Resistance to Infection and Malignancy (ed. E. Skamène, P. A. L. Kongshaven and S. M. Landy), pp. 29-37. New York: Academic Press.

MONJOUR, L., OGUNKOLADE, W., POINTET, P. \& vouldoukis, I. (1985). Parasitologie animale. Efficacité de la vaccination de la souris $\mathrm{C} 57 \mathrm{BL} / 6$ contre l'infection par différentes espèces de Leishmania Comptes Rendus de l'Academie des Sciences, Paris 18 , 803-6.

MONJOUR, L., OGUNKOLADE, W., vOULDOUKIS, I., ROSETo, A., BERNEMAN, A. \& FROMMEL, D. (1986). Immunoprophylaxis against Leishmania infection with a semi-purified antigen. Transactions of the Royal Society of Tropical Medicine and Hygiene 80, 1013. MOSMAN, T. R. \& COFFMAN, R. L. (1987). Two types of mouse helper $\mathrm{T}$ cell clone. Implications for immune regulation. Immunology Today 8, 223-7.

MULLER, I., PEDRAZZiNI, T., FARRELl, J. P. \& LOUIS, J. (1989). T-cell responses and immunity to experimental infection with Leishmania major. Annual Review of Immunology 7 (in the Press). 
Mulliez, PH., Dabouz, R., DEMORY, J. L., DARRAS, A. \& CRINQUETTE, J. (1987). Une observation de leishmaniosa chez un malade traite par corticoides pour sarcoidose. Médecine et Maladies Infectieuses 6/7, 412-13

NADIM, A. \& JAVADIAN, E. (1988). Leishmanization in the Islamic Republic of Iran. In Research on Control Strategies for the Leishmaniases (ed. B. Walton, P. M. Wijeyaretne and F. Modabber), pp. 336-9. Ottawa: International Development Research Centre.

NASSERI, M. \& MODABBER, F. (1979). Generalized infection and lack of delayed hypersensitivity in BALB/c mice infected with Leishmania tropica major. Infection and Immunity 26, 611-14.

PACHECO, R. S., GRIMALDI, G. JR. \& MOREL, C. M. (1987). Inhibition of growth of Leishmania mexicana mexicana by Leishmania mexicana amazonensis during 'in vitro' co-cultivation. Memórias do Instituto Oswaldo Cruz, Rio de Janeiro 82, 537-42.

PEIREIRA, L. H., MELO, A. L., MAYRINK, W. \& DE RESENDE, D. M. D. (1988). A marmoset model for some New World dermatotropic leishmaniases. Parasitologia 30 , (in the Press).

PEREZ, H., LABRADOR, F. \& TORREAlBA, J. W. (1979). Variations in the response of five strains of mice to . Leishmania mexicana. International Journal for Parasitology 9, 27.

PRESTON, P. M., CARTER, R. L., LEUChaRS, E., DAVIES, A. J. S. \& DUMONDE, D. C. (1972). Experimental cutaneous leishmaniasis. III. Effects of thymectomy on the course of infection of CBA mice with Leishmania tropica. Clinical and Experimental Immunology 10, 337-57.

PUENTES, S. M., SACKS, D. L., DA SILVA, P. \& JOINER, K. A. (1988). Complement binding by two developmental stages of Leishmania major promastigotes varying in expression of a surface lipophosphoglycan. Fournal of Experimental Medicine 167, 887-902.

RUSSELL, D. G. \& ALEXANDER, J. (1988). Effective immunization against cutaneous leishmaniasis with defined membrane antigens reconstituted into liposomes. Fournal of Immunology 140, 1274-9.

SACKS, D. L., LAL, S. L., SHRIVASTAVA, S. N., BLACKWELL, J. \& NEVA, F. A. (1987). An analysis of $T$-cell responsiveness in Indian kala-azar. Yournal of Immunology 138, 908-13.

SACKS, D. L. \& PERKINS, P. V. (1984). Identification of an infective stage of Leishmania promastigotes. Science 223, 1417.

SACKS, D. L., SCOTT, P. A., ASOFSKY, R. \& SHER, F. A. (1984). Cutaneous leishmaniasis in anti-IgM-treated mice: enhanced resistance due to functional depletion of a B-cell-dependent $T$ cell involved in the suppressor pathway. Fournal of Immunology 132 , 2072-7.

SCHNUR, L. F., ZUCKERMAN, A. \& GREENBLATT, C. L. (1972). Leishmanial serotypes as distinguished by the gel diffusion of factors excreted in vitro and in vivo. Israel Yournal of Medical Sciences 8, 932-42. SCOTT, P., NATOVITZ, P., COFFMAN, R. L., PEARCE, E. \&
SHER, A. (1988). Immunoregulation of cutaneous leishmaniasis: T-cell lines which transfer protective immunity or exacerbation belong to different TH subsets and respond to distinct parasite antigens. Journal of Experimental Medicine 168, 1675-84.

SCOTT, P., PEARCE, E., NATOVITZ, P. \& SHER, A. (1987).

Vaccination against cutaneous leishmaniasis in a murine model. II. Immunologic properties of protective and nonprotective subfractions of a soluble promastigote extract. Fournal of Immunology 139 , 3118-25.

SENALDi, G., CADEO, G., CARnevale, G., DI PERRI, G. \& CAROSI, G. (1986). Visceral leishmaniasis as an opportunistic infection. The Lancet i 1094.

SOLBACH, W., GREIL, J. \& ROLLINGHOFF, M. (1987). Antiinfectious responses in Leishmania major-infected BALB/c mice injected with recombinant granulocyte-macrophage colony-stimulating factor. Annales de l'Institut Pasteur/Immunologie 138, 759-62.

TITUS, R. G., LIMA, G. C., ENGERS, H. D. \& LOUIS, J. A. (1984). Exacerbation of murine cutaneous leishmaniasis by adoptive transfer of parasite-specific helper T-cell populations capable of mediating $L$. major specific delayed type hypersensitivity. Journal of Immunology 133, 1594-1600.

Titus, R. G., Milon, G., MARChal, G., VASSALli, P., CEROTTINI, J. C. \& LOUIS, J. A. (1987). Involvement of specific Lyt-2+T cells in the immunological control of experimentally induced murine cutaneous leishmaniasis. European Fournal of Immunology 17, 1429-33.

TITUS, R. G. \& RIBEIRO, J. (1988). Salivary gland lysates from the sand fy Lutzomyia longipalis enhance Leishmania infectivity. Science 239, 1306-8.

TURCO, S. J., HULL, S. R., ORLANDI, P. A. JR., SHEPHERD, S. D., HOMANS, S. W., DWEK, R. A. \& RADEMACHER, T. W. (1987). Structure of the major carbohydrate fragment of the Leishmania donovani lipophosphoglycan. Biochemistry 26, 6233-8.

VERDEJO, J., ALVAR, J., POLO, R. M. \& LAHOZ, G. J. M. (1987). Leishmaniasis visceral asociada a anti-HTLV III positivo. Revista Clinica Española 180, 221.

WALTON, B. C., HARPER III, J. \& NEAL, R. A. (1983). Effectiveness of allopurinol against Leishmania braziliensis panamensis in Aotus trivirgatus. American Fournal of Tropical Medicine and Hygiene 32, 46-50.

WIRTH, D. \& MCMAHON-PRATT, D. (1982). Rapid identification of Leishmania species by specific hybridization of kinetoplast DNA in cutaneous lesions. Proceedings of the National Academy of Sciences, USA 79, 6999-7003.

WOZENCRAFT, A. O. \& BLACKWELL, J. M. (1987). Increased infectivity of stationary-phase promastigotes of Leishmania donovani : correlation with enhanced $\mathrm{C} 3$ binding capacity and CR3-mediated attachment to host macrophages. Immunology 60, 559-63.

WYLER, D. J., WEINBAUM, F. I. \& HERROD, H. R. (1979). Characterization of in vitro proliferative responses of human lymphocytes to leishmanial antigens. Fournal of Infectious Diseases 140, 215-21. 